\title{
Abscopal effect of radiotherapy combined with immune checkpoint inhibitors
}

\author{
Yang Liu' ${ }^{1,2}$, Yinping Dong ${ }^{1,2}$, Li Kong ${ }^{2}$, Fang Shi ${ }^{2}$, Hui Zhu ${ }^{2,1^{*}}$ and Jinming $\mathrm{Yu}^{2,1^{*}}$
}

\begin{abstract}
Radiotherapy (RT) is used routinely as a standard treatment for more than $50 \%$ of patients with malignant tumors. The abscopal effect induced by local RT, which is considered as a systemic anti-tumor immune response, reflects the regression of non-irradiated metastatic lesions at a distance from the primary site of irradiation. Since the application of immunotherapy, especially with immune checkpoint inhibitors, can enhance the systemic anti-tumor response of RT, the combination of RT and immunotherapy has drawn extensive attention by oncologists and cancer researchers. Nevertheless, the exact underlying mechanism of the abscopal effect remains unclear. In general, we speculate that the immune mechanism of RT is responsible for, or at least associated with, this effect. In this review, we discuss the anti-tumor effect of RT and immune checkpoint blockade and discuss some published studies on the abscopal effect for this type of combination therapy. In addition, we also evaluate the most appropriate time window for the combination of RT and immune checkpoint blockade, as well as the optimal dose and fractionation of RT in the context of the combined treatment. Finally, the most significant purpose of this review is to identify the potential predictors of the abscopal effect to help identify the most appropriate patients who would most likely benefit from the combination treatment modality.
\end{abstract}

Keywords: Cancer, Radiotherapy, Immunotherapy, Abscopal effect

\section{Background}

Radiotherapy (RT) is a treatment for malignant tumors that has been used for the past century and has been applied to approximately $50 \%$ of all cancer patients [1-3], including patients with newly diagnosed cancers and those with persistent or recurrent tumors. Historically, radiation-induced deoxyribonucleic acid (DNA) damage, which leads to direct tumor cell death by the process of tumor cell apoptosis, senescence, and autophagy [4-6], is considered to be the major mechanism by which most solid tumors respond to clinical ionizing radiation [7]. Since these cytotoxic effects can also affect leukocytes, RT has been considered to be immunosuppressive. For example, the phenomenon of lymphopenia following RT has been observed in patients with solid tumors, including breast cancer, lung cancer, and head and neck tumors [8-10]. In addition, total body irradiation (TBI) has been widely used as a conditioning regimen for

\footnotetext{
*Correspondence: drzhuh@126.com; sdyujinming@163.com

${ }^{2}$ Department of Radiation Oncology, Shandong Cancer Hospital affiliated to

Shandong University, Shandong Academy of Medical Sciences, 440 Jiyan

Road, Jinan 250117, Shandong, China

${ }^{1}$ School of Medicine and Life Sciences, University of Jinan-Shandong

Academy of Medical Sciences, Jinan, Shandong, China
}

patients who require the treatment for bone marrow transplantation [11]. However, radiation-induced activation of the immune system has been increasingly recognized in recent years, an indication that RT could also elicit immune-mediated anti-tumor responses. In fact, the role of $\mathrm{T}$ cells in local tumor control induced by RT was demonstrated in a murine fibrosarcoma model over 30 years ago. The required radiation dose to control $50 \%$ of the tumors was much lower in immunocompetent mice compared to that of T cell-deficient mice (30 gray [Gy] vs. $64.5 \mathrm{~Gy}$ ), and immunocompetent mice also had a lower incidence of metastases than immunosuppressed mice [12]. Similarly, in mouse melanoma tumor models, Lee et al. demonstrated that only immunocompetent hosts responded to 15-20 Gy radiation, while nude mice lacking $\mathrm{T}$ cells and $\mathrm{B}$ cells and wild-type mice depleted of CD8+ T cells did not respond to this high-dose radiation [13]. In patients, Holecek and Harwood reported that one Kaposi's sarcoma patient who previously received a kidney transplant and was treated with azathioprine to suppress kidney rejection responded less to irradiation than those who did not receive an exogenously administered immunosuppressive agent [14].

(c) The Author(s). 2018 Open Access This article is distributed under the terms of the Creative Commons Attribution 4.0 International License (http://creativecommons.org/licenses/by/4.0/), which permits unrestricted use, distribution, and 
Furthermore, other studies have found that this immune-mediated anti-tumor effect of RT could also trigger the regression of metastatic tumors that were distant from the irradiated field, which is the so-called abscopal effect. This effect, initially defined by Mole in 1953 [15], was detected in renal cell carcinoma, melanoma, lymphomas, hepatocellular carcinoma, and other tumor types [16-23]. For instance, Stamell et al. reported a metastatic melanoma patient who received palliative RT to the primary tumor also experienced regression of non-irradiated metastases [17]. An abscopal effect has also been reported in mouse tumor models in which Demaria et al. observed that the abscopal effect was tumor-specific and only occurred in wild-type mice that were treated with a combination of RT and Flt3-L, a growth factor that stimulates the production of dendritic cells (DCs). But no growth delay of secondary non-irradiated tumors has been observed in immunodeficient athymic mice or in wild-type mice treated with single dose of RT alone, further confirming that the abscopal effect was mediated by immune mechanisms [24].

However, although the abscopal effect of RT alone has been reported by a growing number of trials and cases, the overall occurrence rate was relatively low. This may be explained by the insufficiency of RT alone to overcome the immunoresistance of malignant tumors. Given that immunotherapy can reduce host's immune tolerance toward tumors, it is possible that the combination of RT and immunotherapy can amplify the anti-tumor immune response, which is more likely to cause the occurrence of an abscopal effect [25-27]. In fact, this synergistic anti-tumor effect has been investigated in many clinical studies (Table 1). Nevertheless, the mechanism of the abscopal effect is not yet completely understood. Therefore, in this review, we describe the anti-tumor effect of RT and immune checkpoint blockade and discuss several publications on the abscopal effect of combination therapy, primarily to define the potential predictors of this effect so that the appropriate patients could receive more appropriate treatment. In addition, the second aim of this review is to evaluate the optimal timing for coupling RT with immune checkpoint blockade and to determine the most effective dose and fractionation of RT in the context of combination treatments.

\section{RT reprograms the tumor microenvironment}

Under the selective pressure of the immune system, cancer cells have evolved a series of immune resistance mechanisms to escape the elimination of the anti-tumor immune responses, which is known as immunoediting $[28,29]$. Some tumors lack the appropriate inflammatory cytokines and chemokines to attract immune cells, such as DCs, macrophages, and cytotoxic T cells, to the tumor site, and the expression of immunosuppressive ligands and death ligands inhibits the function and the activation of $\mathrm{T}$ cells. In addition, the downregulation of adhesion molecules, such as vascular cell adhesion molecule 1 (VCAM1) and intercellular adhesion molecule 1 (ICAM1), leads to an enhancement of a tumor vasculature barrier that inhibits $\mathrm{T}$ cell arrest and transmigration. Along with other immunosuppressive factors, such as the existence of inhibitory immune cells and the downregulation of the major histocompatibility complex (MHC), these complex interaction mechanisms contribute to cancer cell escape $[30,31]$. However, although these immune escape mechanisms lead to the growth and invasion of tumors, the immune system can still recognize and clear tumor cells, and interventions such as RT that can promote the release of tumor neoantigens may potentially lead to effective immune responses and cancer control. Importantly, under certain conditions, RT can reprogram the anti-immunologic tumor microenvironment, making it more conducive for antigen-presenting cells (APCs) and $\mathrm{T}$ cells to recruit and function, thereby inducing tumor cells to be recognized and eradicated more easily by the immune system.

\section{Radiation-induced release of cytokines and chemokines}

Localized radiation induces a burst release of cytokines and chemokines, giving rise to an inflammatory tumor microenvironment. These factors are secreted by irradiated tumor cells and other cells such as fibroblasts, myeloid cells, and macrophages. Various types of cytokines and chemokines play different roles in modulating the immune response, either pro- or anti-immunogenic, and maintain a net balance in the tumor milieu.

Radiation-induced interferons (IFNs), which represent the main effector molecules of the anti-tumor immune response, play a significant role in the therapeutic effect of RT. The induction of type I IFN by RT is essential for the activation and function of DCs and T cells, which, in turn, is responsible for the release of IFN- $\gamma$ and tumor control $[32,33]$. IFN- $\gamma$ (type II IFN) acts on tumor cells to induce the upregulation of VCAM-1 and MHC-I expression, thereby enhancing the presentation of tumor antigens [34]. Indeed, type I IFN non-responsive mice showed an abolished anti-tumor effect of RT, and an exogenous increase in type I IFN could mimic the therapeutic effect of RT on tumor regression [32]. The production of type I IFN after irradiation is mediated by the stimulator of interferon genes (STING) and its upstream cyclic guanosine monophosphate-adenosine monophosphate synthase (cGAS) signaling pathways by sensing cancer cell-derived cytosolic DNA [35]. This process can be detected in both cancer cells and in infiltrating DCs [36]. However, high-dose radiation, specifically a single dose above a threshold ranging from 12 to $18 \mathrm{~Gy}$, would 


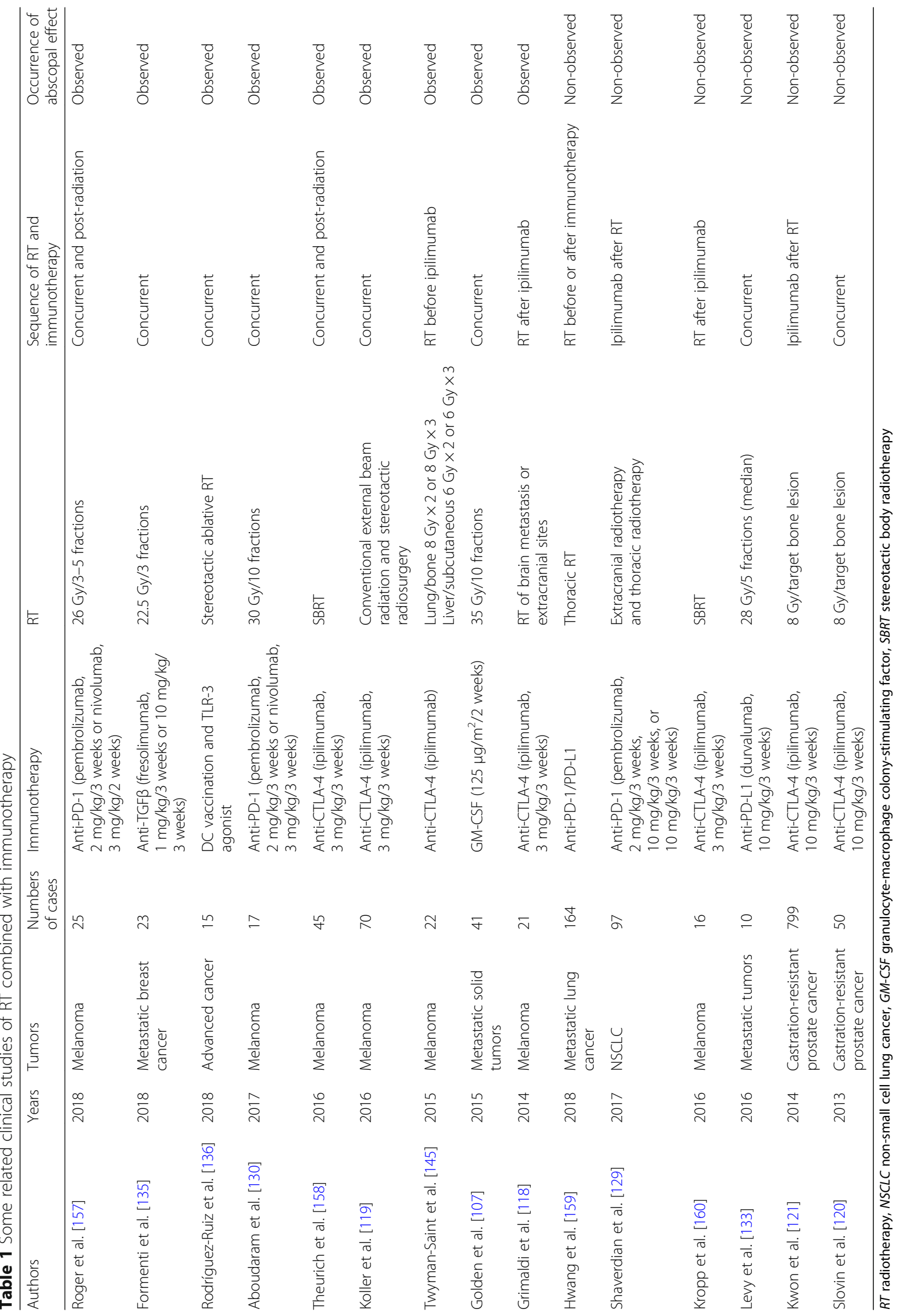


induce upregulation of the three prime repair exonuclease 1 (Trex 1) in tumor cells. Trex 1 is a DNA nuclease which can degrade cytoplasmic DNA and in turn preclude the induction of type I IFN mediated by the activation of the cGAS-STING pathway, demonstrating the radiation dose dependency of the activation of type I IFN signaling [37, 38].

Transforming growth factor beta (TGF $\beta$ ), acting as a major immunosuppressive factor, is also released and activated during RT [39]. This radiation-induced pleiotropic cytokine is important in regulating tissue homeostasis in the tumor microenvironment that inhibits the immune response by reducing the antigen-presenting ability of DCs and the activation of effector T cells [40]. In addition, TGF $\beta$ also causes radioresistance of tumor cells and reduces their radiosensitivity [41]. Taken together, the RT-mediated release of TGF $\beta$ promotes tumorigenesis and metastasis and leads to poor clinical outcomes for patients [42].

The release of other radiation-induced cytokines in the tumor microenvironment also influences the delicate balance between immune clearance and immune tolerance. For instance, the induction of interleukin-6 (IL-6), IL-10, and colony stimulating factor 1 (CSF-1) contributes to the proliferation and invasion of tumor cells and thereby displays a pro-tumorigenic role [43-46]. In contrast, the secretion of pro-inflammatory IL- $1 \beta$ enhances the anti-tumor immune response [47, 48]. Furthermore, the differential expression of RT-induced chemokines determines the type of leukocyte infiltration in the tumor microenvironment. For example, the production of CXC-motif chemokine ligand 12 (CXCL12) results in chemotaxis of pro-tumorigenic $\mathrm{CD} 11 \mathrm{~b}+$ myeloid-derived cells [49], whereas the upregulation of CXCL9, CXCL10, and CXCL16 can attract anti-tumor effector T cells [5052]. These conflicting mechanisms reflect the complexity of the tumor microenvironment.

\section{Radiation-induced infiltration of leukocytes}

The radiation-induced release of inflammatory cytokines and chemokines increases tumor infiltration by various leukocytes including not only leukocytes that enhance anti-tumor immune responses, such as DCs, effector $\mathrm{T}$ cells, and natural killer (NK) cells [53-55], but also immunosuppressive cells such as regulatory $\mathrm{T}$ cells (Treg cells) and CD11b+ cells, including myeloid-derived suppressor cells (MDSCs) and tumor-associated macrophages (TAMs) [56-59].

RT can induce the maturation of DCs and facilitate their migration to draining lymph nodes. These migratory tumor-associated DCs are important in the presentation of tumor antigens, which endogenously trigger the priming of antigen-specific effector $\mathrm{T}$ cells and their subsequent infiltration into tumors [53, 54]. In addition, radiation-induced normalization of the vasculature allows for more efficient infiltration of effector $\mathrm{T}$ cells [60]. In fact, the presence of tumor-infiltrating $\mathrm{T}$ cells has been shown to correlate with better clinical outcomes in patients with a variety of cancers such as colorectal cancer, ovarian cancer, and breast cancer [61-63]. In addition, NK cell-mediated cytotoxicity also plays a significant role in eliminating tumor cells, which can be enhanced by RT since radiation increases the expression of tumor ligands for NK cell-activating receptors, such as NKG2D and NKp30 [64-66].

Treg cells are a special type of $\mathrm{CD} 4+\mathrm{T}$ cells, and they play a key role in maintaining tumor immune tolerance. In the tumor microenvironment, accumulated Treg cells can secrete relative immunosuppressive cytokines such as TGF $\beta$ and IL-10, which impair the antigen-presenting function of DCs and the activation of effector T cells. In addition, Treg cells can also promote tumor angiogenesis and enhance MDSCs to exert their immunosuppressive function, eventually leading to tumor progression [67]. MDSCs are heterogeneous myeloid cells consisting of two major subsets: granulocytic MDSC (G-MDSC) and monocytic MDSC (M-MDSC) [68, 69]. Both populations contribute to tumor progression not only by their negative regulatory effects on the immune system but also by promoting tumor cell invasion and metastasis [70]. Many studies have reported the presence of increased numbers of Treg cells and MDSCs after RT in the tumor microenvironment, which is associated with poor prognosis in cancer patients $[56,57,71]$.

Macrophages are another type of leukocyte that can infiltrate the tumor microenvironment. They can be described by two phenotypes, M1 and M2 macrophages, that have different functions [72]. The classical activation of M1 macrophages can induce the release of pro-inflammatory cytokines such as IL-12 and tumor necrosis factor (TNF) and play a role in killing tumor cells. In contrast, M2 macrophages act as anti-immunogenic cells that express anti-inflammatory cytokines such as IL-10 and TGF $\beta$, which subsequently inhibit the function of effector T cells and favor tumor progression [73]. Indeed, most TAMs are tumor-promoting M2 macrophages [74]. Interestingly, in a pancreatic tumor model, Klug et al. have reported that low-dose irradiation could reprogram the differentiation of TAMs to an M1 phenotype and enhance anti-tumor immunity [75]. Further studies are required to elucidate the effect of RT on TAMs.

\section{Radiation-induced increased susceptibility of tumor cells} RT can also increase the susceptibility of tumor cells to immune-mediated tumor rejection. Upregulation of MHC-I molecules after RT has been observed in many studies. For example, Reits et al. observed that ionizing radiation, particularly at higher doses (10-26 Gy), could 
enhance the expression of MHC-I in a dose-dependent manner in both in vitro and in vivo studies, which increased the presentation of tumor antigens and rendered tumor cells more susceptible to T cell attack [76]. In addition, RT can induce the expression of Fas and ICAM-1 on tumor cells, rendering them more sensitive to $\mathrm{T}$ cell-mediated lysis, which can be blocked by the administration of anti-FasL [77]. Nevertheless, RT can also upregulate the expression of negative immune checkpoint ligands such as programmed death-ligand 1 (PD-L1) and impair the anti-tumor immune responses of effector $\mathrm{T}$ cells $[78,79]$. Therefore, the influence of $\mathrm{RT}$ on the tumor microenvironment is very complex because of its dual effects on the host immune system. These opposing mechanisms for radiation are summarized in Table 2.

\section{Anti-tumor immune effects of RT: from local to abscopal}

\section{RT generates in situ vaccination}

RT can promote a special functional type of cell apoptosis named immunogenic cell death (ICD) [80-82] and can stimulate antigen-specific, adaptive immunity by some undetermined mechanisms [83]. ICD leads to subsequent anti-tumor immune responses including the release of tumor antigens by irradiated tumor cells, the cross-presentation of tumor-derived antigens to T cells by APCs, and the migration of effector $\mathrm{T}$ cells from the lymph nodes to distant tumor sites. These processes illustrate that irradiated tumors can act as an in situ vaccination $[82,84,85]$.

Due to the stress response that is induced by irradiation, the dying tumor cells experience a series of

Table 2 The dual effects of RT on tumor microenvironment

\begin{tabular}{lll}
\hline Effect of RT & Pro-immunogenic & Anti-immunogenic \\
\hline Cytokine secretion & IFN I & TGF- $\beta$ \\
& IFN II & CSF-1 \\
& IL-1 $\beta$ & IL-6 \\
IL-18 & IL-10 \\
Chemokine secretion & CXCL9 & CXCL12 \\
& CXCL10 & \\
LXCL16 & \\
Leukocyte infiltration & DCS & MDSCs \\
& Effector T cells & Treg cells \\
Signal molecule expression & M1 macrophages & M2 macrophages \\
& MHC-1 & PD-L1 \\
& STING & Trex 1 \\
& Fas & \\
\hline
\end{tabular}

$R T$ radiotherapy, IFN interferon, IL interleukin, TGF transforming growth factor, CSF colony-stimulating factor, CXCL CXC-motif chemokine ligand, DCs dendritic cells, MDSCs myeloid-derived suppressor cells, Treg regulatory T lymphocytes, MHC major histocompatibility complex, STING stimulator of interferon genes, Trex three prime repair exonuclease, $P D-L 1$ programmed cell death-ligand 1 subtle changes involving the pre-apoptotic translocation of endoplasmic reticulum (ER) proteins, such as calreticulin (CRT) [82, 86], from the ER to the cell surface, and the release of damage-associated molecular pattern molecules (DAMPs) [87], such as high-mobility group box 1 (HMGB1) [88] and adenosine triphosphate (ATP) $[89,90]$ from the cytoplasm of stressed tumor cells to the outside environment. CRT, acting as an "eat-me" signal, promotes the uptake of irradiated tumor cells by APCs such as DCs and phagocytic cells [86, 90-92]. The release of DAMPs, including HMGB1 and ATP, is another characteristic change that occurs during cell death after exposure to radiation [93, 94]. Acting as a "find-me" signal to recruit APCs [95], ATP can attract monocytes and DCs to tumors by a purinergic receptor P2X7-dependent pathway and promote the secretion of pro-inflammatory cytokines such as IL-1 $\beta$ and IL-18 $[96,97]$. HMGB1 is a histone chromatin-binding protein [98], and when it binds to the surface pattern recognition receptors (PRRs), such as Toll-like receptor (TLR) 2 and TLR 4, it exerts its potential pro-inflammatory effect [94]. This interaction drives downstream inflammation responses and promotes the processing and presentation of tumor antigens by host APCs [94, 98]. Additionally, HMGB1 can also facilitate the maturation of DCs, thereby enabling them to present antigens efficiently to $\mathrm{T}$ cells, a process that is mediated by type I IFNs [57]. As mentioned before, the production of type I IFNs depends on the activation of the cGAS-STING pathway by sensing cancer cell-derived DNA and can be impaired by the DNA nuclease Trex $1[37,38]$. All of these processes contribute to the effective presentation of tumor antigens by DCs and exert potent immunomodulatory effects.

DCs interact with tumor antigens and then migrate to the lymph nodes where they present these antigens to $\mathrm{T}$ cells, a process that is mediated by the MHC pathway via recognition by the $\mathrm{T}$ cell receptor (TCR). Furthermore, the basic leucine zipper ATF-like transcription factor 3 (BATF3)-dependent DC subset has been recently shown to be essential for the cross-priming of CD8 + T cells, which are key effectors in anti-tumor immunity. These DCs can take up tumor antigens effectively and introduce these antigens by way of the MHC class I cross-presenting pathway. Indeed, Batf3 ${ }^{-/-}$mice exhibit an impaired ability to cross-prime cytotoxic $\mathrm{T}$ lymphocytes against tumor antigens $[99,100]$.

However, antigen-MHC complex interactions alone are insufficient to lead to the activation of $\mathrm{T}$ cells; other co-stimulatory signals such as CD80, CD40 L, and CD28 are also required [84]. After activation by multiple signals, $\mathrm{T}$ cells, especially the CD8+ T cells that play a major role in the anti-tumor immune response, are activated and begin to propagate. As a result, activated effector T cells exit the lymph nodes and home to tumors to exert their effect of 
killing tumor cells [101]. This mechanism can be used to explain the regression of distant metastatic tumor lesions combined with the locally irradiated tumors (Fig. 1). In fact, following the first report of the abscopal effect [15], the regression of distant tumor lesions after RT had been documented by many case reports of several malignant tumors such as melanoma, breast cancer, and lung cancer [18, 102, 103]. However, the overall incidence of the abscopal effect is low, and only 46 clinical cases of the abscopal effect due to RT alone have been reported from 1969 to 2014 [104]. This rare phenomenon can be explained by the insufficiency of RT alone to overcome the established immune tolerance mechanisms of tumor cells. Currently, many studies have shown that combining RT with immunotherapy can effectively overcome tumor immunosuppression and boost abscopal response rates compared with the use of RT alone [105-107].

\section{Immunotherapy enhances the systemic anti-tumor response of RT CTLA-4 and CTLA-4 blockade}

As previously mentioned, the activation of T cells requires an interaction between the TCR and a peptide-MHC complex with APCs, as well as a dynamic balance between the co-stimulatory and inhibitory signals that regulate the effectiveness of the immune response. Among them, the binding of CD28 on T cells with the B7 family ligands CD80 and CD86 that are located on APCs is the dominating co-stimulatory signal. Because another trans-membrane receptor, cytotoxic $\mathrm{T}$ lymphocyte-associated antigen 4 (CTLA-4), can also combine with CD80/86, it has been considered as one of the major negative immunomodulatory receptors that attenuate $\mathrm{T}$ cell activation [108-110] (Fig. 1). Therefore, the blockade of CTLA-4 is considered to be a promising immunotherapeutic method for enhancing the anti-tumor immune response, and a series of preclinical and clinical trials have demonstrated the anti-tumor effect of the CTLA-4 blockade in solid tumors, largely in patients with malignant melanoma. For example, two clinical trials have demonstrated that treatment of patients with advanced melanoma using anti-CTLA-4 (ipilimumab) could lead to durable responses and improve the overall survival of patients [111, 112]. Furthermore, patients with ovarian cancer, prostate cancer, and renal cell carcinoma could also benefit from anti-CTLA-4 immunotherapy [113-115].

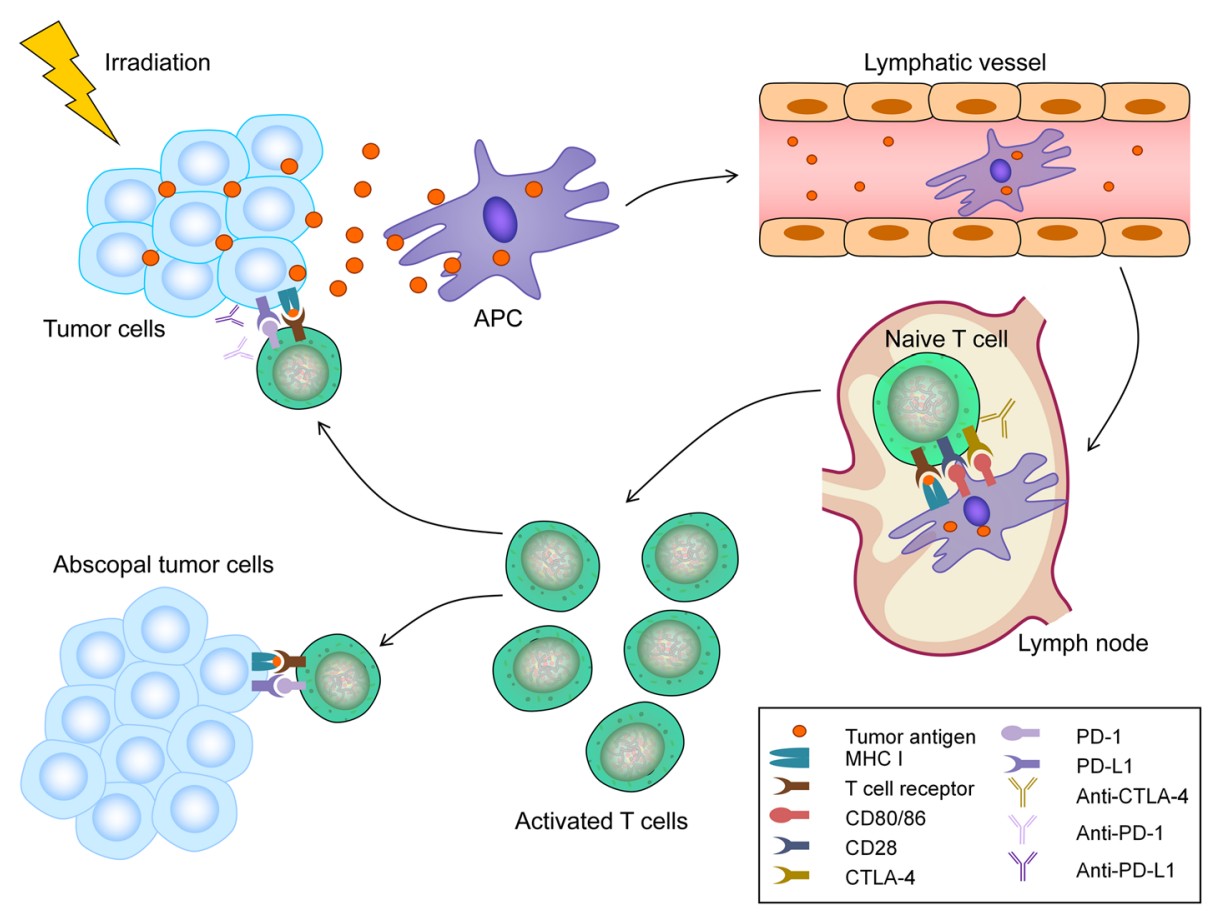

Fig. 1 Mechanism of the abscopal effect. Radiotherapy (RT) can lead to immunogenic cell death and the release of tumor antigens by irradiated tumor cells. These neoantigens are taken up by antigen-presenting cells (APCs), such as dendritic cells (DCs) and phagocytic cells. The APCs interact with tumor antigens and then migrate to the lymph nodes where they present antigens to $T$ cells, a process that is mediated by the MHC pathway and other co-stimulatory signals, such as CD80 and CD28. After activation by multiple signals, T cells, especially the CD8+ T cells, are activated and begin to propagate. As a result, activated effector $T$ cells exit the lymph nodes and home to tumors, including primary tumors and non-irradiated tumor metastases, to exert their effect of killing tumor cells. However, cytotoxic T lymphocyte-associated antigen 4 (CTLA-4) competitively combines with CD80/86 and inhibits the activation of T cells. Following $T$ cell activation, programmed cell death 1 (PD-1) receptors that are expressed on the T cell surface bind primarily to programmed death-ligand 1 (PD-L1) and inhibit immune responses. The administration of immune checkpoint blockades of CTLA-1, PD-1, and PD-L1 can enhance the anti-tumor immunity of RT 
However, the anti-tumor effect of CTLA-4 blockade alone is limited, and monotherapy may lead to serious autoimmune-related side effects such as dermatitis, colitis, hepatitis, and hypophysitis [116]. Given that blocking CTLA-4 could enhance the activation of T cells and increase the ratio of CD8 $+\mathrm{T}$ cells to Treg cells [117], which can strengthen the in situ vaccination effect of RT [110], the combined application of ipilimumab with RT has been increasingly valued by researchers and clinicians. In fact, this combination treatment strategy has achieved encouraging results in studies in both mice and humans and has been approved for the treatment of metastatic melanoma by the US Food and Drug Administration [111]. In a retrospective study, Grimaldi et al. documented a promising outcome for advanced melanoma patients treated with ipilimumab followed by RT. Among 21 patients, 11 patients (52\%) experienced the abscopal effect, including 9 that had a partial response (PR) and 2 that had stable disease (SD). The median overall survival (OS) for patients with the abscopal effect was 22.4 months vs. 8.3 months for patients who did not experience this effect [118]. Consistently, in another retrospective analysis, Koller et al. demonstrated that advanced melanoma patients who received ipilimumab in combination with concurrent RT had a significantly increased median OS and complete response rates compared to those who did not [119]. Additionally, in a phase I/II study, Slovin et al. compared ipilimumab monotherapy with ipilimumab combined with RT (single fraction of $8 \mathrm{~Gy}$ ) for patients with metastatic castration-resistant prostate cancer (mCRPC). The outcome was positive, in that among the 10 patients who received combination therapy, 1 had a PR and 6 had SD, and this combined approach of CTLA-4 blockade and RT could lead to durable disease control of mCRPC [120].

However, the outcomes were not always positive. In a clinical phase III trial, Kwon et al. also investigated the benefit of combination therapy with ipilimumab and RT in patients with $\mathrm{mCRPC}$. Surprisingly, there were no differences in the median OS for the ipilimumab group compared to the placebo group, although reductions in prostate-specific antigen (PSA) concentration and improved progression-free survival (PFS) with ipilimumab treatment have been observed [121]. Therefore, additional studies are required to address this undetermined synergistic anti-tumor activity of combining RT with CTLA-4 blockade.

\section{PD-1/PD-L1 and PD-1/PD-L1 blockade}

Another co-inhibitory molecule, the inhibitory immune receptor programmed cell death 1 (PD-1), is expressed on the plasma membranes of T cells, DCs, and NK cells. PD-1 interferes with $\mathrm{T}$ cell-mediated signaling primarily through interactions with its two cognate ligands, PD-L1 and
PD-L2, which are expressed by tumor cells. In fact, the expression of PD-L1 is upregulated in tumor cells, and PD-1 ligation by PD-L1 mainly promotes $\mathrm{T}$ cell apoptosis and leads to the elimination of activated $\mathrm{T}$ cells, thereby protecting tumor cells from $\mathrm{T}$ cell recognition and elimination [122-125]. Importantly, the upregulation of PD-L1 can be observed in experimental mouse tumor models after exposure to hypofractionated RT, which plays a key role in the RT resistance mechanism of tumor cells [79]. Consequently, we can hypothesize that the combination of the PD-1/PD-L1 blockade and RT may overcome tumor immunosuppression and improve the systemic effect of RT (Fig. 1). In fact, anti-PD-1/PD-L1 monoclonal antibodies (mAbs) have shown promising results in the treatment of non-small cell lung cancer (NSCLC), melanoma, and kidney cancer [126]. Additionally, two immune checkpoint inhibitors of PD-1, pembrolizumab and nivolumab, were approved by the US Food and Drug Administration for clinical application in patients with metastatic melanoma who experienced disease progression after prior treatment [127, 128].

In a secondary analysis of the KEYNOTE-001 phase trial, Shaverdian et al. assessed 97 advanced NSCLC patients who were treated with pembrolizumab. Patients who previously received RT achieved a significantly longer PFS (hazard ratio [HR] 0.56, $p=0.019$; median PFS 4.4 vs. 2.1 months) and OS (HR 0.58, $p=0.026$; median OS 10.7 vs. 5.3 months) than patients who did not previously receive RT [129]. Similarly, in a retrospective collection of consecutive patients with metastatic melanoma and who received PD-1 immune checkpoint inhibitors, Aboudaram et al. compared the survival data, overall response rates, and acute and delayed toxicities between patients receiving concurrent irradiation (IR) or no irradiation (NIR). Among 59 patients who received PD-1 blockade, 17 received palliative $\mathrm{RT}$ with a mean dose of 30 Gy that were delivered in 10 fractions. The objective response rate, including complete and partial response rates, was significantly higher in the IR group versus the NIR group (64.7 vs. $33.3 \%, p=0.02)$ after a 10-month median follow-up and one complete responder experienced an abscopal effect. The 6-month disease-free survival (DFS) and OS rates were marginally increased in the IR group versus the NIR group ( $64.7 \%$ vs. $49.7 \%, p=0.32 ; 76.4 \%$ vs. $58.8 \%, p=0.42$, respectively). Furthermore, no additional side effects were observed in the IR group, and the combination treatment was well tolerated [130]. In addition, abscopal effects have also been reported in patients with other malignant tumors, such as lung adenocarcinoma and Hodgkin's lymphoma [131, 132]. However, in a single-center subset analysis from a phase I/II trial, Levy et al. reported that among 10 patients with metastatic tumors who received palliative local RT for 15 isolated lesions, the objective response (OR) rate was 60\% 
after concurrent palliative RT and anti-PD-L1 durvalumab. Surprisingly, no outfield or abscopal effects were observed [133]. Therefore, although there are many encouraging reports concerning the combination of RT and anti-PD-1/ PD-L1 mAbs, the rate of occurrence of abscopal effects is still undetermined. It is of significance to identify those patients who are most likely to respond, and additional or ongoing trials will hopefully elucidate their characteristics.

\section{Other agents}

Granulocyte-macrophage colony-stimulating factor (GM-CSF) is a potent stimulator of DC differentiation, proliferation, and maturation and facilitates the presentation of tumor antigens after cell death caused by RT [134]. In a prospective study conducted by Golden et al., the enrolled subjects were patients who had stable or advanced metastatic solid tumors after receiving single-agent chemotherapy or hormone therapy and had three distant measurable lesions. These patients were treated with RT (35 Gy in 10 fractions) to one metastatic site along with concurrent GM-CSF $\left(125 \mu \mathrm{g} / \mathrm{m}^{2}\right)$. In the space of 9 years, abscopal effects were observed in 11 of 41 accrued patients (specifically in 2 patients with thymic cancer, 4 with NSCLC, and 5 with breast cancer). In addition, the risk of death for patients without an abscopal effect was more than twice that of patients with it. This prospective clinical trial first demonstrated that an abscopal effect could provide patients with a better survival benefit and suggested a promising combination of RT with GM-CSF to establish an in-site anti-tumor vaccine [107].

Other immunotherapy modalities are still under investigation. Recently, Formenti et al. examined the role of anti-TGF $\beta$ therapeutics during RT to induce an abscopal effect in metastatic breast cancer patients. Fresolimumab, a TGF $\beta$-blocking antibody, was administered in two doses, along with focal radiation of 22.5 Gy in three fractions. Although there was a general lack of abscopal effects, patients who received a higher fresolimumab dose had a significantly lower risk of death and a longer OS (median OS 16.00 vs. 7.57 months, $p=0.039$ ) than those receiving a lower dose [135]. In addition, in another phase I clinical trial, Rodríguez-Ruiz et al. evaluated an intensive treatment modality in advanced cancer patients, which combined RT with two immune interventions, namely, intradermal DC vaccinations and intratumoral injections of Hiltonol, a TLR-3 agonist that can activate elements of both innate and adaptive immunity. The results demonstrated that this combined treatment was well tolerated, and one prostate cancer patient experienced an abscopal response [136]. Many other immunotherapeutic agents such as agonistic CD40 mAb and anti-galectin-1 may also boost abscopal effects by targeting different aspects of the immune-mediated response [137, 138]. In summary, combining these cancer immunotherapy modalities with standard-of-care chemoradiotherapy is a new frontier for future cancer treatment that may provide better efficacy. A brief summary of the representative ongoing clinical trials concerning the combination treatment of RT and immunotherapy is shown in Table 3.

\section{Future directions to improve abscopal effects of RT}

Optimal dose and fractionation of RT in abscopal effects

There are three dominant schemes of RT: conventional fractionation schemes (1.8 2.2 Gy/fraction, one fraction/ day, 5 days/week for 3 7 weeks), hypofractionation including stereotactic radiosurgery $(3 \sim 20 \mathrm{~Gy} /$ fraction, one fraction/day), and hyperfractionation (0.5 2.2 Gy/fraction, two fractions/day, 2 5 fractions/week for 2 4 weeks). The dose and fractionation of RT can influence its modulatory effects on the immune system, but it is worth noting that immunological effects of different regimens are unpredictable. Given that repetitive daily delivery of irradiation can kill migrating immune lymphocytes, Siva et al. believe that conventional fractionation schemes of RT are negative for radiation-induced anti-tumor immune responses. Their group also determined that single high-dose (12 Gy) RT did not deplete established immune effector cells such as CD8+ T cells and NK cells and that it might be much more efficient to kill tumor cells when combined with immunotherapy [139]. Indeed, compared with conventional modalities, RT with ablative high-dose per fractionation has been considered as a better treatment protocol to enhance the anti-tumor immune response [140]. Furthermore, in murine breast and colon cancer models, Dewan et al. showed that $5 \times 6$ Gy and $3 \times 8$ Gy protocols of RT were more effective in inducing immune-mediated abscopal effects than a single ablative dose of 20 Gy when combined with anti-CTLA-4 hamster mAbs 9H10 [141]. Similarly, in a murine melanoma model, Schaue et al. found that fractionated treatment with medium-size radiation doses of $7.5 \mathrm{~Gy} /$ fraction produced the best tumor control and anti-tumor immune responses [142]. Based on these experiences, many clinical trials aiming to evaluate the systematic anti-tumor effect of combinatorial immunotherapy and RT are designed with hypofractionated RT. It is encouraging that some of these studies have achieved satisfactory results and have observed the occurrence of abscopal effects. However, although larger doses per fraction may boost abscopal responses, other clinical studies did not achieve good outcomes, implying that abscopal effects are influenced by multiple factors (Table 1). Based on the dose and the fractionation of RT, an optimal threshold or range of doses is likely to exist. In a recent study, Vanpouille-Box et al. found that a radiation dose 
Table 3 Representative ongoing clinical trials using CTLA-4/PD-1/PD-L1 inhibitors and RT for malignant tumors

\begin{tabular}{|c|c|c|c|c|c|}
\hline $\begin{array}{l}\text { ClinicalTrials.gov } \\
\text { identifier }\end{array}$ & Phase & Conditions & Drug classification & Interventions & Sponsors \\
\hline NCT01996202 & Phase 1 & Melanoma & CTLA-4 inhibitors & $\begin{array}{l}\text { Ipilimumab with radiation } \\
\text { therapy }\end{array}$ & Duke University \\
\hline NCT02642809 & Phase 1 & EC & PD-1 inhibitors & $\begin{array}{l}\text { Pembrolizumab with } \\
\text { brachytherapy (16 Gy in } 2 \\
\text { fractions) }\end{array}$ & $\begin{array}{l}\text { Washington University } \\
\text { School of Medicine }\end{array}$ \\
\hline NCT02837263 & Phase 1 & Colorectal cancer & PD-1 inhibitors & $\begin{array}{l}\text { Pembrolizumab with SBRT } \\
\text { (40-60 Gy in } 5 \text { fractions) }\end{array}$ & $\begin{array}{l}\text { University of Wisconsin, } \\
\text { Madison }\end{array}$ \\
\hline NCT02587455 & Phase 1 & Thoracic tumors & PD-1 inhibitors & $\begin{array}{l}\text { Arm I: pembrolizumab with } \\
\text { low-dose radiation therapy } \\
\text { Arm II: pembrolizumab with } \\
\text { high-dose radiation therapy }\end{array}$ & $\begin{array}{l}\text { Royal Marsden NHS } \\
\text { Foundation Trust }\end{array}$ \\
\hline NCT03151447 & Phase 1 & TNBC & PD-L1 inhibitors & JS001 with SBRT & Fudan University \\
\hline NCT02868632 & Phase 1 & Pancreatic cancer & $\begin{array}{l}\text { PD-L1 and CTLA-4 } \\
\text { inhibitors }\end{array}$ & $\begin{array}{l}\text { Durvalumab or/and } \\
\text { tremelimumab with SBRT } \\
\text { ( } 30 \text { Gy in } 5 \text { fractions) }\end{array}$ & $\begin{array}{l}\text { New York University School } \\
\text { of Medicine }\end{array}$ \\
\hline NCT03275597 & Phase 1 & NSCLC & $\begin{array}{l}\text { PD-L1 and CTLA-4 } \\
\text { inhibitors }\end{array}$ & $\begin{array}{l}\text { Durvalumab and } \\
\text { tremelimumab with SBRT } \\
\text { (30-50 Gy in } 5 \text { fractions) }\end{array}$ & $\begin{array}{l}\text { University of Wisconsin, } \\
\text { Madison }\end{array}$ \\
\hline NCT02239900 & Phase $1 / 2$ & $\begin{array}{l}\text { Liver cancer, } \\
\text { lung cancer }\end{array}$ & CTLA-4 inhibitors & Ipilimumab with SBRT & $\begin{array}{l}\text { M.D. Anderson Cancer } \\
\text { Center }\end{array}$ \\
\hline NCT03050554 & Phase 1/2 & NSCLC & PD-L1 inhibitors & $\begin{array}{l}\text { Avelumab with SBRT ( } 48 \text { Gy in } 4 \\
\text { fractions or } 50 \text { Gy in } 5 \text { fractions) }\end{array}$ & Andrew Sharabi \\
\hline NCT02696993 & Phase $1 / 2$ & $\begin{array}{l}\text { Brain metastases } \\
\text { (NSCLC) }\end{array}$ & $\begin{array}{l}\text { PD-1 and CTLA-4 } \\
\text { inhibitors }\end{array}$ & $\begin{array}{l}\text { Arm I: nivolumab with stereotactic } \\
\text { radiosurgery } \\
\text { Arm II: nivolumab with whole } \\
\text { brain radiation therapy } \\
\text { Arm III: nivolumab and } \\
\text { ipilimumab with stereotactic } \\
\text { radiosurgeryArm } \\
\text { IV: nivolumab and ipilimumab } \\
\text { with whole brain radiation } \\
\text { therapy }\end{array}$ & $\begin{array}{l}\text { M.D. Anderson Cancer } \\
\text { Center }\end{array}$ \\
\hline NCT01970527 & Phase 2 & Melanoma & CTLA-4 inhibitors & Ipilimumab with SBRT & University of Washington \\
\hline NCT02609503 & Phase 2 & Head and neck cancer & PD-1 inhibitors & $\begin{array}{l}\text { Pembrolizumab with radiation } \\
\text { therapy }\end{array}$ & $\begin{array}{l}\text { UNC Lineberger } \\
\text { Comprehensive Cancer } \\
\text { Center }\end{array}$ \\
\hline NCT02730130 & Phase 2 & $\begin{array}{l}\text { Metastatic breast } \\
\text { cancer }\end{array}$ & PD-1 inhibitors & $\begin{array}{l}\text { Pembrolizumab with radiation } \\
\text { therapy }\end{array}$ & $\begin{array}{l}\text { Memorial Sloan Kettering } \\
\text { Cancer Center }\end{array}$ \\
\hline NCT02992912 & Phase 2 & Metastatic tumors & PD-L1 inhibitors & $\begin{array}{l}\text { Atezolizumab with SBRT } \\
\text { (45 Gy in } 3 \text { fractions) }\end{array}$ & $\begin{array}{l}\text { Gustave Roussy, Cancer } \\
\text { Campus, Grand Paris }\end{array}$ \\
\hline NCT03122509 & Phase 2 & $\begin{array}{l}\text { Metastatic colorectal } \\
\text { cancer }\end{array}$ & PD-L1 and CTLA-4 inhibitors & $\begin{array}{l}\text { Tremelimumab and } \\
\text { durvalumab with radiation } \\
\text { therapy }\end{array}$ & $\begin{array}{l}\text { Memorial Sloan Kettering } \\
\text { Cancer Center }\end{array}$ \\
\hline NCT02888743 & Phase 2 & $\begin{array}{l}\text { Colorectal cancer } \\
\text { and NSCLC }\end{array}$ & $\begin{array}{l}\text { PD-L1 and CTLA-4 } \\
\text { inhibitors }\end{array}$ & $\begin{array}{l}\text { Arm I: tremelimumab and } \\
\text { durvalumab } \\
\text { Arm II: tremelimumab and } \\
\text { durvalumab with high-dose } \\
\text { radiation therapy } \\
\text { Arm III: tremelimumab and } \\
\text { durvalumab with low-dose } \\
\text { radiation therapy }\end{array}$ & $\begin{array}{l}\text { National Cancer Institute } \\
(\mathrm{NCl})\end{array}$ \\
\hline NCT02701400 & Phase 2 & Recurrent SCLC & $\begin{array}{l}\text { PD-L1 and CTLA-4 } \\
\text { inhibitors }\end{array}$ & $\begin{array}{l}\text { Arm I: tremelimumab and } \\
\text { durvalumab } \\
\text { Arm II: tremelimumab and } \\
\text { durvalumab with SBRT }\end{array}$ & Emory University \\
\hline
\end{tabular}


Table 3 Representative ongoing clinical trials using CTLA-4/PD-1/PD-L1 inhibitors and RT for malignant tumors (Continued)

\begin{tabular}{|c|c|c|c|c|c|}
\hline $\begin{array}{l}\text { ClinicalTrials.gov } \\
\text { identifier }\end{array}$ & Phase & Conditions & Drug classification & Interventions & Sponsors \\
\hline NCT02617589 & Phase 3 & Brain Cancer & PD-1 inhibitors & $\begin{array}{l}\text { Arm I: nivolumab with radiation } \\
\text { therapy } \\
\text { Arm II: temozolomide with } \\
\text { radiation therapy }\end{array}$ & Bristol-Myers Squibb \\
\hline NCT02768558 & Phase 3 & NSCLC & PD-1 inhibitors & $\begin{array}{l}\text { Cisplatin and etoposide } \\
\text { plus radiation followed } \\
\text { by nivolumab }\end{array}$ & RTOG Foundation, Inc. \\
\hline
\end{tabular}

above a threshold of $10-12$ Gy per fraction could attenuate the immunogenicity of cancer cells because of the induced upregulation of the DNA nuclease Trex 1, which can degrade cytoplasmic DNA and inhibit immune activation [37]. Thus, researchers should take these different data into a careful consideration in order to develop an optimal dose and fractionation scheme for RT in the context of radioimmunotherapy combinations to induce anti-tumor abscopal effects efficiently.

\section{Combination time window for RT and immunotherapy}

The optimal schedule for the administration of RT relative to the immune checkpoint inhibitors is currently unclear. Should immune inhibitors of checkpoints be given concomitantly or sequentially with RT, and in which order? This time window may significantly influence the therapeutic anti-tumor response of this combination treatment.

Indeed, different combinatorial schedules have been evaluated in some preclinical studies. For instance, in mouse colon carcinoma models, in which a fractionated RT cycle of 2 Gy $\times 5$ fractions was administered, Dovedi et al. evaluated three different schedules including the administration of anti-PD-L1 mAbs on day 1 of the RT cycle (schedule A), day 5 of the cycle (schedule B), or 7 days after the completion of RT (schedule C). Interestingly, both schedule $\mathrm{A}$ and schedule $\mathrm{B}$ achieved increased OS compared with RT alone, and there was no significant difference in the OS between these two subgroups. In contrast, sequential treatments with delayed administration of anti-PD-L1 mAbs at 7 days after RT completion (schedule C) were completely ineffective for improving the OS when compared with RT alone [143]. Similarly, in a murine breast model, Dewan et al. showed that the administration of anti-CTLA-4 mAbs at 2 days before or on the day of RT achieved a better therapeutic efficacy when compared with the delayed administration of mAbs at 2 days after RT [141]. Furthermore, some clinical case reports also imply the optimal time window of combining RT with immunotherapy. Golden et al. reported an abscopal effect in a treatment-refractory lung cancer patient treated with four three-weekly cycles of ipilimumab (3 $\mathrm{mg} / \mathrm{kg}$ ) and concurrent RT [144]. In addition, in a melanoma patient, Stamell et al. also observed an abscopal effect after combining ipilimumab with stereotactic RT concurrently [17]. Similarly, in the published clinical studies of radioimmunotherapy combinations, abscopal effects were mostly reported in patients who received RT while receiving concomitant immunotherapy (Table 1). Given the experience of preclinical and clinical trials in which abscopal effects were observed, although there is no consensus yet, the administration of immunotherapy initiated before or at the time of delivering RT may be preferred. However, in a phase I clinical trial of 22 advanced melanoma patients, Twyman-Saint et al. found that hypofractionated radiation followed by a treatment with the anti-CTLA4 antibody ipilimumab could also lead to partial responses in the non-irradiated lesions [145]. In addition, the potential toxicity of combination therapy, especially combinatorial radioimmunotherapy with concurrent regimens, limits their clinical application and should be investigated in further studies.

\section{Biomarkers for predicting the abscopal effect}

Although a combination of immunotherapy and RT has achieved promising results in multiple solid tumors, not all of the patients experienced an abscopal effect. Therefore, it is necessary to identify efficient and effective biomarkers that can predict abscopal responses in patients who received combinatorial therapeutic regimens of immunotherapy and RT. In addition, validated biomarkers would be helpful in selecting suitable patients, identifying optimal therapeutic strategies, and predicting treatment responses.

As a tumor suppressor gene, p53 plays an important role in regulating the proliferation, apoptosis, and DNA repair of tumor cells, and its encoded protein P53 is a transcription factor that influences the onset of the cell cycle. As a guardian of the genome, p53 can inhibit the growth of tumors by obstructing the replication of damaged DNA, which acts as a major culprit inducing the abnormal proliferation of tumor cells [146]. However, the probability of a p53 mutation is greater than $50 \%$ among patients with malignant tumors, and a mutant p53 would lose its ability to inhibit the proliferation of 
tumor cells. In recent years, many studies have revealed that the status of p53 could regulate the abscopal anti-tumor effect of RT. In a mouse model system, Strigari et al. demonstrated growth inhibition of non-irradiated wild-type p53 tumors after irradiation of 20 Gy or 10 Gy. However, no significant tumor growth delay was observed in non-irradiated p53-null tumors regardless of the dose delivered [147]. Consistently, Camphausen et al. observed a similar result, in that the abscopal anti-tumor effect was observed neither in p53-null mice nor in mice in which p53 was inhibited by pifithrin- $\alpha$, a drug that can block the p53 pathway [148]. Therefore, we can hypothesize that p53-dependent signals might be responsible for the systemic anti-tumor effect of RT, and an evaluation of the status of p53 in vivo might be used to predict the possibility of the occurrence of abscopal effects for cancer patients treated with RT regimens and thus provide better treatment administration.

In the Grimaldi et al. report on advanced melanoma, an abscopal effect was observed in 11 patients who were treated with ipilimumab followed by RT. Importantly, all patients who achieved an immune-related abscopal effect displayed a local response to RT. Thus, it is reasonable to speculate that a local response to RT could be of use to prognosticate abscopal effects. Furthermore, patients with an abscopal effect had a significantly higher median absolute lymphocyte count (ALC) before RT than those without an abscopal response, implying that lymphocyte counts preceding RT might be another patient parameter that can predict the occurrence of the abscopal effect. Nevertheless, given the limited number of patients in this retrospective study, further investigations are required to evaluate the predictive role of the local response to RT and the ALC on systemic abscopal effects [118].

Calreticulin expression may act as another potential marker to predict the response to combination treatments. As mentioned above, the radiation-induced translocation of calreticulin would promote the uptake of irradiated tumor cells by APCs and enhance the killing effect of T cells [86]. Furthermore, knockdown of calreticulin would impair the $\mathrm{T}$ cell recognition of tumor cells [149]. Therefore, the expression of calreticulin after RT implies susceptibility of tumor cells to T cell killing and can be used as a biomarker for the response to immunotherapy and RT. In addition, a recent preclinical study indicated that Trex 1 can be used as a potential biomarker to guide the administration of an optimal dose and fractionation of RT, which would be helpful in providing a better combination treatment strategy that might overcome the immunosuppression of tumor cells and facilitate the occurrence of abscopal effects [37, 38].

In addition, other biomarkers for immunotherapy have also been widely investigated. For instance, the tumor mutation burden (TMB) is closely related to the anti-cancer effect of immune checkpoint inhibitors, and patients with a high mutation burden experienced a long-term clinical benefit [150-152]. The PD-L1 expression can serve as a potential biomarker for the prediction of response to immunotherapies that target PD-1/PD-L1 [153-156]. However, a predictive role for them in the systemic abscopal effects of combinatorial immunotherapy and RT has yet to be defined. Furthermore, no specific sensitive biomarkers have been determined that can exclusively predict the abscopal responses in patients who experienced combined treatment regimens, and this is still an active area that needs to be further investigated.

\section{Conclusion}

The abscopal effects of RT have been extensively reported in preclinical and clinical studies, and irradiated tumor cell death can stimulate anti-tumor adaptive immunity by promoting the release of tumor antigens and the cross-presentation of tumor-derived antigens to $\mathrm{T}$ cells. However, it is difficult for RT alone to overcome the immunoresistance of malignant tumors. With the development of cancer immunotherapy, especially immune checkpoint inhibitors, the abscopal effect of RT has become more meaningful, since the in situ vaccination that is generated by RT can be substantially potentiated by immunotherapy. Exploiting the synergistic anti-tumor effect of these two treatments is encouraging because of its effective potential to improve the OS and PFS of patients with malignant tumors. However, many challenges remain for this combination treatment, including the determination of optimal dose/fractionation schemes for RT, the administration of optimal time points for these two treatment modalities, and the identification of relative biomarkers for the prediction of treatment efficacy. These challenges need to be addressed in future preclinical and clinical trials. In addition, translating these preclinical data into relevant and clinically efficient treatments and developing evidence-based consensus guidelines for RT and immunotherapy will also be required.

\section{Abbreviations}

ALC: Absolute lymphocyte count; APCs: Antigen-presenting cells; ATP: Adenosine triphosphate; BATF3: Basic leucine zipper ATF-like transcription factor 3; CGAS: Cyclic guanosine monophosphate-adenosine monophosphate synthase; CRT: Calreticulin; CSF-1: Colony stimulating factor 1; CTLA-4: Cytotoxic T lymphocyte-associated antigen 4; CXCL12: CXC-motif chemokine ligand 12; DAMPs: Damage-associated molecular pattern molecules; DCs: Dendritic cells; DFS: Disease-free survival; DNA: Deoxyribonucleic acid; ER: Endoplasmic reticulum; GM-CSF: Granulocyte-macrophage colony-stimulating factor; GMDSC: Granulocytic MDSC; Gy: Gray; HMGB1: High-mobility group box 1; ICAM1: Intercellular adhesion molecule 1; ICD: Immunogenic cell death; IFNs: Interferons; IL-6: Interleukin-6; IR: Irradiation; mAbs: Monoclonal antibodies; mCRPC: Metastatic castration-resistant prostate cancer; MDSCs: Myeloid-derived suppressor cells; MHC: Major histocompatibility complex; M-MDSC: Monocytic MDSC; NIR: No irradiation; NK cells: Natural killer cells; NSCLC: Non-small cell lung cancer; OR: Objective response; OS: Overall survival; PD-1: Programmed cell death 1; PD-L1: Programmed death-ligand 1; PD-L2: Programmed death-ligand 
2; PFS: Progression-free survival; PR: Partial response; PRRs: Pattern recognition receptors; PSA: Prostate-specific antigen; RT: Radiotherapy; SD: Stable disease; STING: Stimulator of interferon genes; TAMs: Tumor-associated macrophages; TBI: Total body irradiation; TCR: T cell receptor; TGF $\beta$ : Transforming growth factor beta; TLR: Toll-like receptor; TMB: Tumor mutation burden; TNF: Tumor necrosis factor; Treg cells: Regulatory T cells; Trex 1: Three prime repair exonuclease 1; VCAM1: Vascular cell adhesion molecule 1

\section{Acknowledgements}

The authors would such as to express their great thanks to the Innovation Project of the Shandong Academy of Medical Science.

\section{Funding}

This work was supported by the Key Research and Development Program of Shandong Province (grant numbers 2016GSF201148 and 2016CYJS01A03).

\section{Availability of data and materials}

The dataset supporting the conclusions of this article is included within the article.

\section{Authors' contributions}

$\mathrm{HZ}$ and JMY designed the study. YL drafted the manuscript. YL, YPD, LK, and FS coordinated, edited, and finalized the drafting of the manuscript. All authors read and approved the final manuscript.

\section{Ethics approval and consent to participate}

Not applicable.

\section{Consent for publication}

Not applicable.

\section{Competing interests}

The authors declare that they have no competing interests.

\section{Publisher's Note}

Springer Nature remains neutral with regard to jurisdictional claims in published maps and institutional affiliations.

\section{Received: 19 April 2018 Accepted: 8 August 2018}

Published online: 16 August 2018

\section{References}

1. Möller TR, Einhorn N, Lindholm C, Ringborg U, Svensson H. Radiotherapy and cancer care in Sweden. Acta Oncol. 2009;42:366-75.

2. Delaney $\mathrm{G}$, Jacob S, Featherstone C, Barton M. The role of radiotherapy in cancer treatment: estimating optimal utilization from a review of evidencebased clinical guidelines. Cancer. 2005:104:1129-37.

3. Jaffray DA. Image-guided radiotherapy: from current concept to future perspectives. Nat Rev Clin Oncol. 2012;9:688-99.

4. Rupnow BA, Murtha AD, Alarcon RM, Giaccia AJ, Knox SJ. Direct evidence that apoptosis enhances tumor responses to fractionated radiotherapy. Cancer Res. 1998:58:1779-84.

5. Dewey WC, Ling CC, Meyn RE. Radiation-induced apoptosis: relevance to radiotherapy. Int J Radiat Oncol Biol Phys. 1995:33:781-96.

6. Eriksson D, Stigbrand T. Radiation-induced cell death mechanisms. Tumou Biol. 2010;31:363-72

7. Ross G. Induction of cell death by radiotherapy. Endocrine Related Cancer 1999;6:41-4

8. Blomgren H, Glas U, Melén B, Wasserman J. Blood lymphocytes after radiation therapy of mammary carcinoma. Acta Radiol Ther Phys Biol. 1974; 13:185-200.

9. Campian $\mathrm{L}$, Ye X, Brock M, Grossman SA. Treatment-related lymphopenia in patients with stage III non-small-cell lung cancer. Cancer Investig. 2013;31: 183-8.

10. Harisiadis L, Kopelson G, Chang CH. Lymphopenia caused by cranial irradiation in children receiving craniospinal radiotherapy. Cancer. 1977;40: 1102-8.

11. Hill-Kayser CE, Plastaras JP, Tochner Z, Glatstein E. TBI during BM and SCT: review of the past, discussion of the present and consideration of future directions. Bone Marrow Transplant. 2011;46:475-84.
12. Stone $H B$, Peters $\sqcup$, Milas $L$. Effect of host immune capability on radiocurability and subsequent transplantability of a murine fibrosarcoma. J Natl Cancer Inst. 1979;63:1229-35.

13. Lee $Y$, Auh SL, Wang $Y$, Burnette $B$, Wang $Y$, Meng $Y$, et al. Therapeutic effects of ablative radiation on local tumor require CD8+ T cells: changing strategies for cancer treatment. Blood. 2009:114:589-95.

14. Holecek MJ, Harwood AR. Radiotherapy of Kaposi's sarcoma. Cancer. 1978; 41:1733-8.

15. Mole RH. Whole body irradiation—radiobiology or medicine? Br J Radiol. 1953;26:234-41.

16. Poleszczuk JT, Luddy KA, Prokopiou S, Robertson-Tessi M, Moros EG Fishman M, et al. Abscopal benefits of localized radiotherapy depend on activated T-cell trafficking and distribution between metastatic lesions. Cancer Res. 2016;76:1009-18.

17. Stamell EF, Wolchok JD, Gnjatic S, Lee NY, Brownell I. The abscopal effect associated with a systemic anti-melanoma immune response. Int J Radiat Oncol Biol Phys. 2013;85:293-5.

18. Postow MA, Callahan MK, Barker CA, Yamada Y, Yuan J, Kitano S, et al. Immunologic correlates of the abscopal effect in a patient with melanoma. N Engl J Med. 2012;366:925-31.

19. Antoniades J, Brady LW, Lightfoot DA. Lymphangiographic demonstration of the abscopal effect in patients with malignant lymphomas. Int J Radiat Oncol Biol Phys. 1977;2:141-7.

20. Robins HI, Buchon JA, Varanasi VR, Weinstein AB. The abscopal effect: demonstration in lymphomatous involvement of kidneys. Med Pediat Oncol. 1981;9:473-6.

21. Kingsley DP. An interesting case of possible abscopal effect in malignant melanoma. Br J Radiol. 1975:48:863-6.

22. Reynders K, Illidge T, Siva S, Chang JY, De Ruysscher D. The abscopal effect of local radiotherapy: using immunotherapy to make a rare event clinically relevant. Cancer Treat Rev. 2015;41:503-10.

23. O'Regan B, Hirshberg C. Spontaneous remission: an annotated bibliography. Petaluma: Institute of Noetic Sciences Sausalito; 1993.

24. Demaria S, Ng B, Devitt ML, Babb JS, Kawashima N, Liebes L, et al. lonizing radiation inhibition of distant untreated tumors (abscopal effect) is immune mediated. Int J Radiat Oncol Biol Phys. 2004:58:862-70.

25. Hodge JW, Sharp HJ, Gameiro SR. Abscopal regression of antigen disparate tumors by antigen cascade after systemic tumor vaccination in combination with local tumor radiation. Cancer Biother Radiopharm. 2012;27:12-22.

26. Demaria S, Kawashima N, Yang AM, Devitt ML, Babb JS, Allison JP, et al. Immune-mediated inhibition of metastases after treatment with local radiation and CTLA-4 blockade in a mouse model of breast cancer. Clin Cancer Res. 2005;11:728-34.

27. Vatner RE, Cooper BT, Vanpouille-Box C, Demaria S, Formenti SC. Combinations of immunotherapy and radiation in cancer therapy. Front Oncol. 2014:4:325

28. Dunn GP, Bruce AT, Ikeda H, Old LJ, Schreiber RD. Cancer immunoediting: from immunosurveillance to tumor escape. Nat Immunol. 2002;3:991-8.

29. Schreiber RD, Old LJ, Smyth MJ. Cancer immunoediting: integrating immunity's roles in cancer suppression and promotion. Science. 2011;331: 1565-70.

30. Vesely MD, Kershaw MH, Schreiber RD, Smyth MJ. Natural innate and adaptive immunity to cancer. Annu Rev Immunol. 2011:29:235-71.

31. Dunn GP, Old LJ, Schreiber RD. The three Es of cancer immunoediting. Annu Rev Immunol. 2004:22:329-60.

32. Burnette BC, Liang $H$, Lee $Y$, Chlewicki L, Khodarev NN, Weichselbaum RR, et al. The efficacy of radiotherapy relies upon induction of type I interferondependent innate and adaptive immunity. Cancer Res. 2011;71:2488-96.

33. Fuertes MB, Kacha AK, Kline J, Woo SR, Kranz DM, Murphy KM, et al. Host type I IFN signals are required for antitumor CD8+ T cell responses through CD8\{alpha\}+ dendritic cells. J Exp Med. 2011;208: 2005-16.

34. Lugade AA, Sorensen EW, Gerber SA, Moran JP, Frelinger JG, Lord EM. Radiation-induced IFN- production within the tumor microenvironment influences antitumor immunity. J Immunol. 2008;180:3132-9.

35. Deng L, Liang $H$, Xu M, Yang X, Burnette $B$, Arina A, et al. STING-dependent cytosolic DNA sensing promotes radiation-induced type I interferon-dependent antitumor immunity in immunogenic tumors. Immunity. 2014:41:843-52.

36. Woo SR, Fuertes MB, Corrales L, Spranger S, Furdyna MJ, Leung MY, et al. STING-dependent cytosolic DNA sensing mediates innate immune recognition of immunogenic tumors. Immunity. 2014;41:830-42. 
37. Vanpouille-Box C, Alard A, Aryankalayil MJ, Sarfraz Y, Diamond JM, Schneider RJ, et al. DNA exonuclease Trex1 regulates radiotherapy-induced tumour immunogenicity. Nat Commun. 2017:8:15618.

38. Vanpouille-Box C, Formenti SC, Demaria S. TREX1 dictates the immune fate of irradiated cancer cells. Oncoimmunology. 2017;6:e1339857.

39. Vanpouille-Box C, Diamond JM, Pilones KA, Zavadil J, Babb JS, Formenti SC, et al. TGFbeta is a master regulator of radiation therapy-induced antitumor immunity. Cancer Res. 2015;75:2232-42.

40. Wrzesinski SH, Wan YY, Flavell RA. Transforming growth factor-beta and the immune response: implications for anticancer therapy. Clin Cancer Res. 2007;13: 5262-70.

41. Bouquet F, Pal A, Pilones KA, Demaria S, Hann B, Akhurst RJ, et al. TGFbeta1 inhibition increases the radiosensitivity of breast cancer cells in vitro and promotes tumor control by radiation in vivo. Clin Cancer Res. 2011;17: 6754-65.

42. Saito H, Tsujitani S, Oka S, Kondo A, Ikeguchi M, Maeta M, et al. An elevated serum level of transforming growth factor-beta 1 (TGF-beta 1) significantly correlated with lymph node metastasis and poor prognosis in patients with gastric carcinoma. Anticancer Res. 2000;20:4489-93.

43. Matsuoka Y, Nakayama H, Yoshida R, Hirosue A, Nagata M, Tanaka T, et al. IL-6 controls resistance to radiation by suppressing oxidative stress via the Nrf2antioxidant pathway in oral squamous cell carcinoma. Br J Cancer. 2016;115: 1234-44.

44. Wojciechowska-Lacka A, Matecka-Nowak M, Adamiak E, Lacki JK, CerkaskaGluszak B. Serum levels of interleukin-10 and interleukin-6 in patients with lung cancer. Neoplasma. 1996;43:155-8.

45. Visco C, Vassilakopoulos TP, Kliche KO, Nadali G, Viviani S, Bonfante V, et al. Elevated serum levels of IL-10 are associated with inferior progression-free survival in patients with Hodgkin's disease treated with radiotherapy. Leuk Lymphoma. 2004;45:2085-92

46. Xu J, Escamilla J, Mok S, David J, Priceman S, West B, et al. CSF1R signaling blockade stanches tumor-infiltrating myeloid cells and improves the efficacy of radiotherapy in prostate cancer. Cancer Res. 2013;73:2782-94.

47. Ghiringhelli F, Apetoh L, Tesniere A, Aymeric L, Ma Y, Ortiz C, et al. Activation of the NLRP3 inflammasome in dendritic cells induces IL-1betadependent adaptive immunity against tumors. Nat Med. 2009;15:1170-8.

48. Calveley VL, Khan MA, Yeung IW, Vandyk J, Hill RP. Partial volume rat lung irradiation: temporal fluctuations of in-field and out-of-field DNA damage and inflammatory cytokines following irradiation. Int J Radiat Biol. 2005;81: 887-99.

49. Kozin SV, Kamoun WS, Huang Y, Dawson MR, Jain RK, Duda DG. Recruitment of myeloid but not endothelial precursor cells facilitates tumor regrowth after local irradiation. Cancer Res. 2010;70:5679-85.

50. Matsumura S, Wang B, Kawashima N, Braunstein S, Badura M, Cameron TO et al. Radiation-induced CXCL16 release by breast cancer cells attracts effector T cells. J Immunol. 2008;181:3099-107.

51. Lim JY, Gerber SA, Murphy SP, Lord EM. Type I interferons induced by radiation therapy mediate recruitment and effector function of CD8(+) T cells. Cancer Immunol Immunother. 2014;63:259-71.

52. Meng Y, Mauceri HJ, Khodarev NN, Darga TE, Pitroda SP, Beckett MA, et al. Ad.Egr-TNF and local ionizing radiation suppress metastases by interferonbeta-dependent activation of antigen-specific CD8+ T cells. Mol Ther. 2010; 18:912-20.

53. Lugade AA, Moran JP, Gerber SA, Rose RC, Frelinger JG, Lord EM. Local radiation therapy of B16 melanoma tumors increases the generation of tumor antigenspecific effector cells that traffic to the tumor. J Immunol. 2005;174:7516-23.

54. Gupta A, Probst HC, Vuong V, Landshammer A, Muth S, Yagita H, et al. Radiotherapy promotes tumor-specific effector CD8+ T cells via dendritic cell activation. J Immunol. 2012;189:558-66.

55. Ni J, Miller M, Stojanovic A, Garbi N, Cerwenka A. Sustained effector function of IL-12/15/18-preactivated NK cells against established tumors. J Exp Med. 2012;209:2351-65.

56. Kachikwu EL, Iwamoto KS, Liao YP, DeMarco JJ, Agazaryan N, Economou JS, et al. Radiation enhances regulatory T cell representation. Int J Radiat Oncol Biol Phys. 2011:81:1128-35.

57. Wu CY, Yang LH, Yang HY, Knoff J, Peng S, Lin YH, et al. Enhanced cancer radiotherapy through immunosuppressive stromal cell destruction in tumors. Clin Cancer Res. 2014;20:644-57.

58. Du R, Lu KV, Petritsch C, Liu P, Ganss R, Passegue E, et al. HIF1alpha induces the recruitment of bone marrow-derived vascular modulatory cells to regulate tumor angiogenesis and invasion. Cancer Cell. 2008;13:206-20.
59. Laoui D, Van Overmeire E, De Baetselier P, Van Ginderachter JA, Raes G. Functional relationship between tumor-associated macrophages and macrophage colony-stimulating factor as contributors to cancer progression. Front Immunol. 2014;5:489.

60. Barker HE, Paget JT, Khan AA, Harrington KJ. The tumour microenvironment after radiotherapy: mechanisms of resistance and recurrence. Nat Rev Cancer. 2015;15:409-25.

61. Galon J, Costes A, Sanchez-Cabo F, Kirilovsky A, Mlecnik B, Lagorce-Pages C, et al. Type, density, and location of immune cells within human colorectal tumors predict clinical outcome. Science. 2006;313:1960-4.

62. Hwang WT, Adams SF, Tahirovic E, Hagemann IS, Coukos G. Prognostic significance of tumor-infiltrating T cells in ovarian cancer: a meta-analysis. Gynecol Oncol. 2012;124:192-8.

63. Mahmoud SM, Paish EC, Powe DG, Macmillan RD, Grainge MJ, Lee AH, et al. Tumor-infiltrating CD8+ lymphocytes predict clinical outcome in breast cancer. J Clin Oncol Off J Am Soc Clin Oncol. 2011;29:1949-55.

64. Morvan MG, Lanier LL. NK cells and cancer: you can teach innate cells new tricks. Nat Rev Cancer. 2016;16:7-19.

65. Kim JY, Son YO, Park SW, Bae JH, Chung JS, Kim HH, et al. Increase of NKG2D ligands and sensitivity to NK cell-mediated cytotoxicity of tumor cells by heat shock and ionizing radiation. Exp Mol Med. 2006;38:474-84.

66. Matta J, Baratin M, Chiche L, Forel JM, Cognet C, Thomas G, et al. Induction of $\mathrm{B} 7-\mathrm{H} 6$, a ligand for the natural killer cell-activating receptor NKp30, in inflammatory conditions. Blood. 2013;122:394-404.

67. Facciabene A, Motz GT, Coukos G. T-regulatory cells: key players in tumor immune escape and angiogenesis. Cancer Res. 2012;72:2162-71.

68. Youn Jl, Gabrilovich DI. The biology of myeloid-derived suppressor cells: the blessing and the curse of morphological and functional heterogeneity. Eur J Immunol. 2010;40:2969-75.

69. Movahedi K, Guilliams M, Van den Bossche J, Van den Bergh R, Gysemans C, Beschin A, et al. Identification of discrete tumor-induced myeloid-derived suppressor cell subpopulations with distinct T cell-suppressive activity. Blood. 2008;111:4233-44.

70. Condamine T, Ramachandran I, Youn Jl, Gabrilovich DI. Regulation of tumor metastasis by myeloid-derived suppressor cells. Annu Rev Med. 2015;66:97-110.

71. Kumar V, Patel S, Tcyganov E, Gabrilovich DI. The nature of myeloid-derived suppressor cells in the tumor microenvironment. Trends Immunol. 2016;37: 208-20.

72. Mantovani A, Bottazzi B, Colotta F, Sozzani S, Ruco L. The origin and function of tumor-associated macrophages. Cell Mol Immunol. 1992;265:265-70.

73. Mantovani A, Sozzani S, Locati M, Allavena P, Sica A. Macrophage polarization: tumor-associated macrophages as a paradigm for polarized M2 mononuclear phagocytes. Trends Immunol. 2002;23:549-55.

74. Huang Y, Snuderl M, Jain RK. Polarization of tumor-associated macrophages: a novel strategy for vascular normalization and antitumor immunity. Cancer Cell. 2011;19:1-2.

75. Klug F, Prakash H, Huber PE, Seibel T, Bender N, Halama N, et al. Low-dose irradiation programs macrophage differentiation to an iNOS(+)/M1 phenotype that orchestrates effective T cell immunotherapy. Cancer Cell. 2013;24:589-602.

76. Reits EA, Hodge JW, Herberts CA, Groothuis TA, Chakraborty M, Wansley EK, et al. Radiation modulates the peptide repertoire, enhances MHC class I expression, and induces successful antitumor immunotherapy. J Exp Med. 2006:203:1259-71.

77. Chakraborty M, Abrams SI, Camphausen K, Liu K, Scott T, Coleman CN, et al. Irradiation of tumor cells up-regulates Fas and enhances CTL Iytic activity and CTL adoptive immunotherapy. J Immunol. 2003;170:6338-47.

78. Verbrugge I, Hagekyriakou J, Sharp LL, Galli M, West A, McLaughlin NM, et al. Radiotherapy increases the permissiveness of established mammary tumors to rejection by immunomodulatory antibodies. Cancer Res. 2012;72:3163-74.

79. Deng L, Liang H, Burnette B, Beckett M, Darga T, Weichselbaum RR, et al. Irradiation and anti-PD-L1 treatment synergistically promote antitumor immunity in mice. J Clin Invest. 2014;124:687-95.

80. Galluzzi L, Kepp O, Kroemer G. Immunogenic cell death in radiation therapy Oncoimmunology. 2013;2:e26536.

81. Kepp O, Galluzzi L, Martins I, Schlemmer F, Adjemian S, Michaud M, et al. Molecular determinants of immunogenic cell death elicited by anticancer chemotherapy. Cancer Metastasis Rev. 2011;30:61-9.

82. Kroemer G, Galluzzi L, Kepp O, Zitvogel L. Immunogenic cell death in cancer therapy. Annu Rev Immunol. 2013;31:51-72.

83. Zelenay S, Reis e Sousa C. Adaptive immunity after cell death. Trends Immunol. 2013;34:329-35. 
84. Herrera FG, Bourhis J, Coukos G. Radiotherapy combination opportunities leveraging immunity for the next oncology practice. CA Cancer J Clin. 2017;67:65-85.

85. Vanpouille-Box C, Pilones KA, Wennerberg E, Formenti SC, Demaria S. In situ vaccination by radiotherapy to improve responses to anti-CTLA-4 treatment. Vaccine. 2015:33:7415-22.

86. Obeid M, Tesniere A, Ghiringhelli F, Fimia GM, Apetoh L, Perfettini JL, et al. Calreticulin exposure dictates the immunogenicity of cancer cell death. Nat Med. 2007;13:54-61.

87. Boone BA, Lotze MT. Targeting damage-associated molecular pattern molecules (DAMPs) and DAMP receptors in melanoma. Methods Mol Biol. 2014;1102:537-52

88. Tang D, Kang R, Zeh HJ 3rd, Lotze MT. High-mobility group box 1, oxidative stress, and disease. Antioxid Redox Signal. 2011;14:1315-35.

89. Elliott MR, Chekeni FB, Trampont PC, Lazarowski ER, Kadl A, Walk SF, et al. Nucleotides released by apoptotic cells act as a find-me signal to promote phagocytic clearance. Nature. 2009;461:282-6.

90. Garg AD, Krysko DV, Verfaillie T, Kaczmarek A, Ferreira GB, Marysael T, et al. A novel pathway combining calreticulin exposure and ATP secretion in immunogenic cancer cell death. EMBO J. 2012;31:1062-79.

91. Gardai SJ, McPhillips KA, Frasch SC, Janssen WJ, Starefeldt A, Murphy-Ullrich JE, et al. Cell-surface calreticulin initiates clearance of viable or apoptotic cells through trans-activation of LRP on the phagocyte. Cell. 2005;123:321-34.

92. Panaretakis T, Kepp O, Brockmeier U, Tesniere A, Bjorklund AC, Chapman $D C$, et al. Mechanisms of pre-apoptotic calreticulin exposure in immunogenic cell death. EMBO J. 2009;28:578-90.

93. Matzinger P. Tolerance, danger, and the extended family. Annu Rev Immunol. 1994;12:991-1045.

94. Marshak-Rothstein A. Toll-like receptors in systemic autoimmune disease Nat Rev Immunol. 2006;6:823-35.

95. Chekeni FB, Elliott MR, Sandilos JK, Walk SF, Kinchen JM, Lazarowski ER, et al. Pannexin 1 channels mediate 'find-me' signal release and membrane permeability during apoptosis. Nature. 2010;467:863-7.

96. Perregaux DG, McNiff P, Laliberte R, Conklyn M, Gabel CA. ATP acts as an agonist to promote stimulus-induced secretion of IL-1 and IL-18 in human blood. J Immunol. 2000;165:4615-23.

97. Gorbunov NV, Garrison BR, Kiang JG. Response of crypt paneth cells in the small intestine following total-body gamma-irradiation. Int J Immunopathol Pharmacol. 2010:23:1111-23.

98. Apetoh L, Ghiringhelli F, Tesniere A, Criollo A, Ortiz C, Lidereau R, et al. The interaction between HMGB1 and TLR4 dictates the outcome of anticancer chemotherapy and radiotherapy. Immunol Rev. 2007;220:47-59.

99. Sanchez-Paulete AR, Cueto FJ, Martinez-Lopez M, Labiano S, MoralesKastresana A, Rodriguez-Ruiz ME, et al. Cancer immunotherapy with immunomodulatory anti-CD137 and anti-PD-1 monoclonal antibodies requires BATF3-dependent dendritic cells. Cancer Discov. 2016;6:71-9.

100. Hildner K, Edelson BT, Purtha WE, Diamond M, Matsushita H, Kohyama M, et al. Batf3 deficiency reveals a critical role for CD8alpha+ dendritic cells in cytotoxic T cell immunity. Science. 2008;322:1097-100.

101. Tabi Z, Spary LK, Coleman S, Clayton A, Mason MD, Staffurth J. Resistance of CD45RA- T cells to apoptosis and functional impairment, and activation of tumor-antigen specific T cells during radiation therapy of prostate cancer. J Immunol. 2010;185:1330-9.

102. Hu Zl, McArthur HL, Ho AY. The abscopal effect of radiation therapy: what is it and how can we use it in breast cancer? Curr Breast Cancer Rep. 2017;9:45-51.

103. Siva S, Callahan J, MacManus MP, Martin O, Hicks RJ, Ball DL. Abscopal [corrected] effects after conventional and stereotactic lung irradiation of non-small-cell lung cancer. J Thorac Oncol. 2013;8:e71-2.

104. Abuodeh $Y$, Venkat P, Kim S. Systematic review of case reports on the abscopal effect. Curr Probl Cancer. 2016;40:25-37.

105. Rodriguez-Ruiz ME, Rodriguez I, Barbes B, Mayorga L, Sanchez-Paulete AR, PonzSarvise M, et al. Brachytherapy attains abscopal effects when combined with immunostimulatory monoclonal antibodies. Brachytherapy. 2017;16:1246-51.

106. Ngwa W, Irabor OC, Schoenfeld JD, Hesser J, Demaria S, Formenti SC. Using immunotherapy to boost the abscopal effect. Nat Rev Cancer. 2018;18:313-22.

107. Golden EB, Chhabra A, Chachoua A, Adams S, Donach M, Fenton-Kerimian $M$, et al. Local radiotherapy and granulocyte-macrophage colonystimulating factor to generate abscopal responses in patients with metastatic solid tumours: a proof-of-principle trial. Lancet Oncol. 2015;16: 795-803.

108. Grosso JF, Jure-Kunkel MN. CTLA-4 blockade in tumor models: an overview of preclinical and translational research. Cancer Immun Arch. 2013;13:5.
109. Salama AK, Hodi FS. Cytotoxic T-lymphocyte-associated antigen-4. Clin Cancer Res. 2011;17:4622-8.

110. Pedicord VA, Montalvo W, Leiner IM, Allison JP. Single dose of anti-CTLA-4 enhances CD8+ T-cell memory formation, function, and maintenance. Proc Natl Acad Sci U S A. 2011;108:266-71.

111. Hodi FS, O'Day SJ, McDermott DF, Weber RW, Sosman JA, Haanen JB, et al. Improved survival with ipilimumab in patients with metastatic melanoma. N Engl J Med. 2010;363:711-23.

112. Robert C, Thomas L, Bondarenko I, O'Day S, Weber J, Garbe C, et al. Ipilimumab plus dacarbazine for previously untreated metastatic melanoma. N Engl J Med. 2011;364:2517-26

113. Hodi FS, Mihm MC, Soiffer RJ, Haluska FG, Butler M, Seiden MV, et al. Biologic activity of cytotoxic T lymphocyte-associated antigen 4 antibody blockade in previously vaccinated metastatic melanoma and ovarian carcinoma patients. Proc Natl Acad Sci U S A. 2003:100:4712-7.

114. Small EJ, Tchekmedyian NS, Rini BI, Fong L, Lowy I, Allison JP. A pilot trial of CTLA-4 blockade with human anti-CTLA-4 in patients with hormonerefractory prostate cancer. Clin Cancer Res. 2007;13:1810-5.

115. Blansfield JA, Beck KE, Tran K, Yang JC, Hughes MS, Kammula US, et al. Cytotoxic T-lymphocyte-associated antigen-4 blockage can induce autoimmune hypophysitis in patients with metastatic melanoma and renal cancer. J Immunother. 2005;28:593-8.

116. Scalapino KJ, Daikh DI. CTLA-4: a key regulatory point in the control of autoimmune disease. Immunol Rev. 2008;223:143-55.

117. Wing $K$, Onishi Y, Prieto-Martin P, Yamaguchi T, Miyara M, Fehervari Z, et al. CTLA-4 control over Foxp3+ regulatory T cell function. Science. 2008;322:271-5.

118. Grimaldi AM, Simeone E, Giannarelli D, Muto P, Falivene S, Borzillo V, et al. Abscopal effects of radiotherapy on advanced melanoma patients who progressed after ipilimumab immunotherapy. Oncoimmunology. 2014;3:e28780.

119. Koller KM, Mackley HB, Liu J, Wagner H, Talamo G, Schell TD, et al. Improved survival and complete response rates in patients with advanced melanoma treated with concurrent ipilimumab and radiotherapy versus ipilimumab alone. Cancer Biol Ther. 2017;18:36-42.

120. Slovin SF, Higano CS, Hamid O, Tejwani S, Harzstark A, Alumkal JJ, et al. Ipilimumab alone or in combination with radiotherapy in metastatic castration-resistant prostate cancer: results from an open-label, multicenter phase I/II study. Ann Oncol. 2013;24:1813-21.

121. Kwon ED, Drake CG, Scher HI, Fizazi K, Bossi A, van den Eertwegh AJM, et al. Ipilimumab versus placebo after radiotherapy in patients with metastatic castration-resistant prostate cancer that had progressed after docetaxel chemotherapy (CA184-043): a multicentre, randomised, double-blind, phase 3 trial. Lancet Oncol. 2014;15:700-12.

122. Dong H, Zhu G, Tamada K, Chen L. B7-H1, a third member of the B7 family, co-stimulates T-cell proliferation and interleukin-10 secretion. Nat Med. 1999:5:1365-9.

123. Latchman Y, Wood CR, Chernova T, Chaudhary D, Borde M, Chernova I, et al. PD-L2 is a second ligand for PD-1 and inhibits T cell activation. Nat Immunol. 2001;2:261-8.

124. Greenwald RJ, Freeman GJ, Sharpe AH. The B7 family revisited. Annu Rev Immunol. 2005;23:515-48.

125. Callahan MK, Wolchok JD. At the bedside: CTLA-4- and PD-1-blocking antibodies in cancer immunotherapy. J Leukoc Biol. 2013;94:41-53.

126. Teng F, Kong L, Meng X, Yang J, Yu J. Radiotherapy combined with immune checkpoint blockade immunotherapy: achievements and challenges. Cancer Lett. 2015;365:23-9.

127. Robert C, Schachter J, Long GV, Arance A, Grob J, Mortier L, et al. Pembrolizumab versus ipilimumab in advanced melanoma. N Engl J Med. 2015;372:2521-32.

128. Weber JS, D'Angelo SP, Minor D, Hodi FS, Gutzmer R, Neyns B, et al. Nivolumab versus chemotherapy in patients with advanced melanoma who progressed after anti-CTLA-4 treatment (CheckMate 037): a randomised, controlled, open-label, phase 3 trial. Lancet Oncol. 2015;16:375-84.

129. Shaverdian N, Lisberg AE, Bornazyan K, Veruttipong D, Goldman JW, Formenti SC, et al. Previous radiotherapy and the clinical activity and toxicity of pembrolizumab in the treatment of non-small-cell lung cancer: a secondary analysis of the KEYNOTE-001 phase 1 trial. Lancet Oncol. 2017;18:895-903.

130. Aboudaram A, Modesto A, Chaltiel L, Gomez-Roca C, Boulinguez S, Sibaud $\checkmark$, et al. Concurrent radiotherapy for patients with metastatic melanoma and receiving anti-programmed-death 1 therapy: a safe and effective combination. Melanoma Res. 2017;27:485-91.

131. Komatsu T, Nakamura K, Kawase A. Abscopal effect of nivolumab in a patient with primary lung cancer. J Thorac Oncol. 2017;12:e143-e4. 
132. Michot JM, Mazeron R, Dercle L, Ammari S, Canova C, Marabelle A, et al. Abscopal effect in a Hodgkin lymphoma patient treated by an antiprogrammed death 1 antibody. Eur J Cancer. 2016;66:91-4.

133. Levy A, Massard C, Soria JC, Deutsch E. Concurrent irradiation with the antiprogrammed cell death ligand-1 immune checkpoint blocker durvalumab: single centre subset analysis from a phase 1/2 trial. Eur J Cancer. 2016;68:156-62.

134. Inaba K. Generation of large numbers of dendritic cells from mouse bone marrow cultures supplemented with granulocyte/macrophage colonystimulating factor. J Exp Med. 1992;176:1693-702.

135. Formenti SC, Lee P, Adams S, Goldberg JD, Li X, Xie MW, et al. Focal irradiation and systemic TGFbeta blockade in metastatic breast cancer. Clin Cancer Res. 2018;24:2493-504.

136. Rodriguez-Ruiz ME, Perez-Gracia JL, Rodriguez I, Alfaro C, Onate C, Perez G, et al. Combined immunotherapy encompassing intratumoral poly-ICLC, dendritic-cell vaccination and radiotherapy in advanced cancer patients. Ann Oncol. 2018;29:1312-9.

137. Vonderheide RH, Glennie MJ. Agonistic CD40 antibodies and cancer therapy. Clin Cancer Res. 2013;19:1035-43.

138. Dalotto-Moreno T, Croci DO, Cerliani JP, Martinez-Allo VC, Dergan-Dylon S, Mendez-Huergo SP, et al. Targeting galectin-1 overcomes breast cancerassociated immunosuppression and prevents metastatic disease. Cancer Res. 2013;73:1107-17.

139. Siva S, MacManus MP, Martin RF, Martin OA. Abscopal effects of radiation therapy: a clinical review for the radiobiologist. Cancer Lett. 2015;356:82-90.

140. Finkelstein SE, Timmerman R, McBride WH, Schaue D, Hoffe SE, Mantz CA, et al. The confluence of stereotactic ablative radiotherapy and tumor immunology. Clin Dev Immunol. 2011;2011:439752.

141. Dewan MZ, Galloway AE, Kawashima N, Dewyngaert JK, Babb JS, Formenti SC, et al. Fractionated but not single-dose radiotherapy induces an immune-mediated abscopal effect when combined with anti-CTLA-4 antibody. Clin Cancer Res. 2009;15:5379-88.

142. Schaue D, Ratikan JA, Iwamoto KS, McBride WH. Maximizing tumor immunity with fractionated radiation. Int J Radiat Oncol Biol Phys. 2012;83:1306-10.

143. Dovedi SJ, Adlard AL, Lipowska-Bhalla G, McKenna C, Jones S, Cheadle EJ, et al. Acquired resistance to fractionated radiotherapy can be overcome by concurrent PD-L1 blockade. Cancer Res. 2014;74:5458-68.

144. Golden EB, Demaria S, Schiff PB, Chachoua A, Formenti SC. An abscopal response to radiation and ipilimumab in a patient with metastatic nonsmall cell lung cancer. Cancer Immunol Res. 2013;1:365-72.

145. Twyman-Saint Victor C, Rech AJ, Maity A, Rengan R, Pauken KE, Stelekati E, et al. Radiation and dual checkpoint blockade activate non-redundant immune mechanisms in cancer. Nature. 2015;520:373-7.

146. Lane DP. Cancer. p53, guardian of the genome. Nature. 1992;358:15-6.

147. Strigari L, Mancuso M, Ubertini V, Soriani A, Giardullo P, Benassi M, et al. Abscopal effect of radiation therapy: interplay between radiation dose and p53 status. Int J Radiat Biol. 2014;90:248-55.

148. Camphausen K, Moses MA, Ménard C, Sproull M, Beecken W-D, Folkman J, et al. Radiation abscopal antitumor effect is mediated through p53. Cancer Res. 2003;63:1990-3.

149. Gameiro SR, Jammeh ML, Wattenberg MM, Tsang KY, Ferrone S, Hodge JW. Radiation-induced immunogenic modulation of tumor enhances antigen processing and calreticulin exposure, resulting in enhanced T-cell killing. Oncotarget. 2014;5:403-16.

150. Snyder A, Makarov V, Merghoub T, Yuan J, Zaretsky JM, Desrichard A, et al. Genetic basis for clinical response to CTLA-4 blockade in melanoma. N Engl J Med. 2014;371:2189-99.

151. Rizvi NA, Hellmann MD, Snyder A, Kvistborg P, Makarov V, Havel JJ, et al. Mutational landscape determines sensitivity to PD-1 blockade in non-small cell lung cancer. Science. 2015;348:124-8.

152. Johnson DB, Frampton GM, Rioth MJ, Yusko E, Ennis R, Fabrizio D, et al. Hybrid capture-based next-generation sequencing (HC NGS) in melanoma to identify markers of response to anti-PD-1/PD-L1. J Clin Oncol. 2016;34:105.

153. Garon EB, Rizvi NA, Hui R, Leighl N, Balmanoukian AS, Eder JP, et al. Pembrolizumab for the treatment of non-small-cell lung cancer. N Engl J Med. 2015;372:2018-28.

154. Herbst RS, Baas P, Kim D-W, Felip E, Pérez-Gracia JL, Han J-Y, et al. Pembrolizumab versus docetaxel for previously treated, PD-L1-positive, advanced non-small-cell lung cancer (KEYNOTE-010): a randomised controlled trial. Lancet. 2016;387:1540-50.
155. Reck M, Rodriguez-Abreu D, Robinson AG, Hui R, Csoszi T, Fulop A, et al Pembrolizumab versus chemotherapy for PD-L1-positive non-small-cell lung cancer. N Engl J Med. 2016;375:1823-33.

156. Topalian SL, Hodi FS, Brahmer JR, Gettinger SN, Smith DC, McDermott DF, et al. Safety, activity, and immune correlates of anti-PD-1 antibody in cancer. N Engl J Med. 2012;366:2443-54.

157. Roger A, Finet A, Boru B, Beauchet A, Mazeron J-J, Otzmeguine Y, et al. Efficacy of combined hypo-fractionated radiotherapy and anti-PD-1 monotherapy in difficult-to-treat advanced melanoma patients. Oncoimmunology. 2018;7:e1442166.

158. Theurich S, Rothschild SI, Hoffmann M, Fabri M, Sommer A, Garcia-Marquez $M$, et al. Local tumor treatment in combination with systemic ipilimumab immunotherapy prolongs overall survival in patients with advanced malignant melanoma. Cancer Immunol Res. 2016:4:744-54.

159. Hwang WL, Niemierko A, Hwang KL, Hubbeling H, Schapira E, Gainor JF, et al. Clinical outcomes in patients with metastatic lung cancer treated with PD-1/PD-L1 inhibitors and thoracic radiotherapy. JAMA Oncol. 2018;4:253-5.

160. Kropp LM, De Los Santos JF, McKee SB, Conry RM. Radiotherapy to control limited melanoma progression following ipilimumab. J Immunother. 2016; 39:373-8
Ready to submit your research? Choose BMC and benefit from:

- fast, convenient online submission

- thorough peer review by experienced researchers in your field

- rapid publication on acceptance

- support for research data, including large and complex data types

- gold Open Access which fosters wider collaboration and increased citations

- maximum visibility for your research: over 100M website views per year

At BMC, research is always in progress.

Learn more biomedcentral.com/submissions 